\title{
Smoking and its association with cryptorchidism in Down syndrome
}

\author{
Adrianne Maria Berno de Rezende Duarte ${ }^{1}$, José de Bessa Júnior ${ }^{2 *}$, Flávia Cristina de Carvalho Mrad ${ }^{1}$, \\ Sandra Helena Cerrato Tibiriçá ${ }^{1}$, Maíra lorenzo de Sá Camargo ${ }^{1}$, Augusto Alves Pinto Vieira ${ }^{1}$, \\ Frederico Cantarino Cordeiro Araujo ${ }^{1}$, André Avarese de Figueiredo ${ }^{1}$, José Murillo de Bastos-Netto ${ }^{1,3}$ \\ ${ }^{1}$ Universidade Federal de Juiz de Fora, Juiz de Fora, MG, Brazil \\ ZUniversidade Estadual de Feira de Santana, Feira de Santana, BA, Brazil \\ ${ }^{3}$ Hospital Maternidade Therezinha de Jesus, Faculdade de Ciências Médicas e da Saúde de Juiz de Fora, Juiz de Fora, MG, Brazil
}

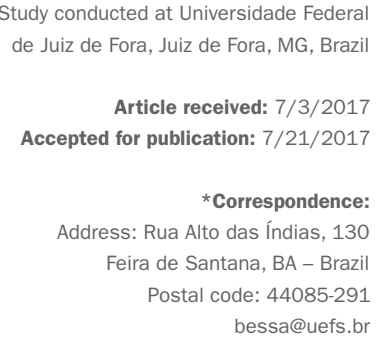

*Correspondence: Address: Rua Alto das Índias, 130 Feira de Santana, BA - Brazil Postal code: 44085-291 bessa@uefs.br

\section{SUMmARY}

Introduction: Cryptorchidism is a common and prevalent condition in patients with Down syndrome. Environmental factors, such as smoking, can be associated with malformations during fetal development. The study of the prevalence of cryptorchidism and its association with parental tobacco use in Down syndrome can contribute to alert health care professionals, patients and family members regarding the prevention of the harms caused by cryptorchidism and its possible predisposing factors.

Objective: To evaluate the prevalence of cryptorchidism in Down syndrome and its association with maternal and paternal smoking.

Method: Forty (40) patients of a public clinic specialized in Down syndrome were evaluated, using a semi-structured questionnaire for evaluation of antecedents and sociodemographic characteristics, as well as physical and complementary examinations. Results: Cryptorchidism was observed in $27.5 \%$ of the patients (95CI 15.98-42.96). Of these, 55\% (5/9) were the children of mothers who smoked during pregnancy, and $19.35 \%$ (6/31) were the children of mothers who did not smoke during pregnancy $(\mathrm{OR}=5.26$ [95CI 1.06-25.41]; $\mathrm{p}=0.032)$. Similarly, paternal smoking was also observed in greater frequency among the parents of cryptorchid patients compared with subjects with descended testis, 63.36\% (7/11) and 31.03\% (9/29), respectively $(\mathrm{OR}=3.89$ [95CI 0.91-16.73]; $\mathrm{p}=0.060)$.

Conclusion: The prevalence of cryptorchidism is high in patients with Down syndrome. We can show a strong association between smoking parents and the occurrence of cryptorchidism, especially when it comes to maternal smoking.

Keywords: smoking, Down syndrome, cryptorchidism, urologic diseases.

\section{INTRODUCTION}

The technological advances in perinatology in the contemporary world are undisputed, yet pregnancy and birth are frequently surrounded by uncertainty, distress and anxiety.

There is a great number of etiologic factors known to favor congenital malformations, including heredity, alcohol, smoking, pesticides, illicit drugs, infection with cytomegalovirus, rubella or toxoplasmosis, and exposure to medicinal substances and radiation. ${ }^{1}$ Environmental factors can be responsible for many congenital defects. ${ }^{2}$ Among them, cigarettes, which are socially accepted, globally spread, and historically consumed by both women and men, predispose to fetal $^{3}$ and chromosome malformations. ${ }^{2}$
Down syndrome (DS), caused by trisomy 21 (HSA21), is the most frequent genetic anomaly, ${ }^{2,4-8}$ occurring in one of every 319 to 1,000 births. ${ }^{2,9-11}$ In Brazil, 300,000 people have $\mathrm{DS}^{12}$ and it is estimated that one case of DS occurs in every 600 to 800 births, ${ }^{13}$ about 8,000 cases per year, which may or may not be associated with comorbidities such as cardiac, gastrointestinal, respiratory, renal and urogenital (cryptorchidism and hypospadias) malformations, hypothyroidism, leukemia, Alzheimer's disease, and more. ${ }^{14-20}$

Multiple congenital malformations related to DS include urogenital ones, so that cryptorchidism and hypospadias have been reported..$^{20,21}$ It is suspected that the 
lifestyle of mothers and environmental exposures during pregnancy may interfere with the normal testicular descent, increasing the risk of urogenital malformations. ${ }^{19-22}$

The aims of our study were to evaluate the prevalence of cryptorchidism and its association with parental smoking in patients with Down syndrome.

\section{Method}

This is an observational study in which patients of a public clinic specialized in Down syndrome of the Department of Child and Adolescent Health, in our area, were evaluated using a semi-structured questionnaire for antecedents and sociodemographic characteristics, as well as receiving physical and complementary examinations.

The project was approved by the institution's Research Ethics Committee, and those responsible for the participants signed an informed consent form.

The data are expressed as mean \pm standard deviation (SD), median and interquartile interval, or absolute values and fractions. Student's t-test or Mann-Whitney test, ANOVA or Kruskall-Wallis were used to compare the continuous variables, while categorical variables were compared using Fisher's exact test or Chi-square test. Odds ratio and confidence intervals of $95 \%$ were used to describe the magnitude of the association between categorical variables. All the tests were two-sided, with $\mathrm{p}<0.05$ considered statistically significant. Analyses were conducted using a commercially available statistical software (Graph Pad Prism, version 6.03 for Windows, San Diego, California, U.S.A.).

\section{Results}

Of the 166 patients registered in the Down Syndrome Clinic, contact was possible with 114 (68.7\%), of which 40 (35.1\%) were male. Cryptorchidism was observed in 11 patients in the evaluated sample, indicating a prevalence of $27.5 \%$ (95CI 15.98-42.96). In these patients, cryptorchidism was observed in 55\% (5/9) of children with smoking mothers and in $19.35 \%$ (6/31) of those whose mothers did not smoke (OR $=5.26$ [95CI 1.06-25.41]; $\mathrm{p}=0.032$ ) (Figure 1).

Similarly, paternal smoking was also observed in greater frequency among the parents of cryptorchid patients compared with subjects with descended testis, $63.36 \%(7 / 11)$ and $31.03 \%(9 / 29)$, respectively $(\mathrm{OR}=3.89$ [95CI 0.91-16,73]; $\mathrm{p}=0.060)$. The age of the mothers was $27.1 \pm 6.17$ and that of the fathers was $31.4 \pm 7.25$ years.

\section{Discussion}

The occurrence of cryptorchidism in this series was $27.5 \%$, similarly to observed in the literature, where ectopic testis was found in 14 to $27 \%$ of patients with DS. This is the most frequent urogenital tract abnormality in this population. ${ }^{22}$ The high prevalence and drawbacks reinforce the idea that such a condition cannot be neglected in the clinical evaluation of children with Down syndrome.

Cigarette smoke contains mutagenic and carcinogenic agents, ${ }^{3}$ as well as toxic agents, which can lead to fetal alterations $\mathrm{s}^{23-25}$ such as in the reproductive function stages (folliculogenesis, steroidogenesis, embryo transport,

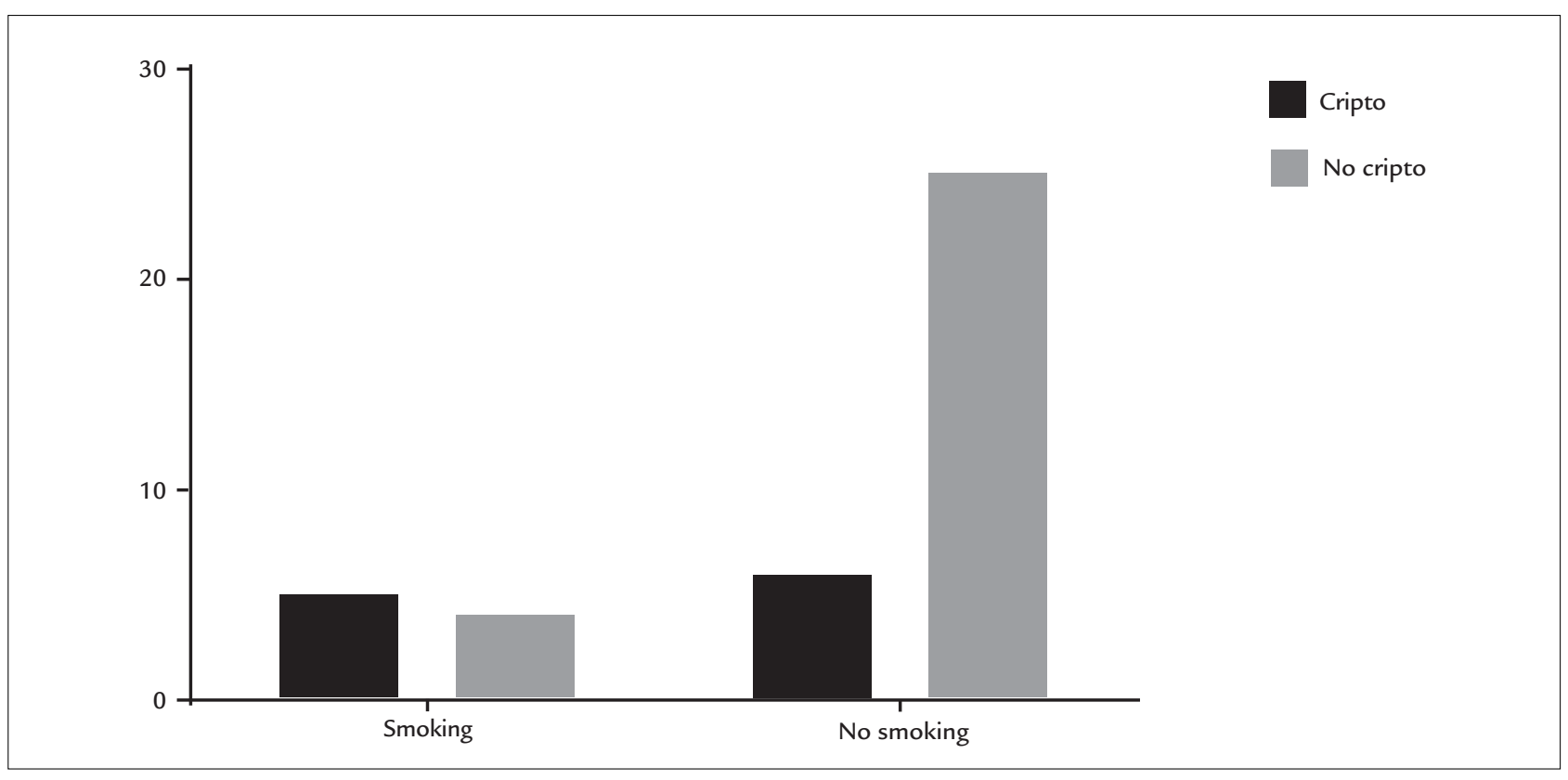

FIGURE 1 Position of the testis according to maternal smoking habit. 
endometrial receptivity, angiogenesis, uterine blood flow and in the uterine myometrium) and the occurrence of chromosome malformations. ${ }^{2}$

Furthermore, ectopic testis can be associated with cancer in an occurrence estimated to be 3 to 48 times higher than in the general population. ${ }^{26-28}$ Cryptorchidism is one of the main predisposing factors for seminoma tumors. ${ }^{27,28}$

Maternal smoking, as well as use of nicotine substitutes, was previously associated with an increased risk in the reduction of spermatozoids and cryptorchidism..$^{1,15}$ An increased risk of cryptorchidism was also observed among sons of mothers who smoked ten cigarettes or more per day during pregnancy. ${ }^{16}$

According to other authors, there has been a positive association between paternal exposure to pesticides and paternal smoking with cryptorchidism. ${ }^{26}$

Our results corroborate these findings. The possible adverse effects of maternal smoking were incontestable. Limitations due to the size of the sample make it impossible for us to show a statistically significant association with paternal smoking. We believe that studies with larger samples, and with greater power, can confirm this association.

According to data in the literature, the risk of hypospadias seems to increase with the age of the mother, mainly when she is over 40 years old, as well as with other factors, such as the use of progesterone in the beginning of pregnancy and smoking parents. ${ }^{21,22,26}$ Although there are uncertainties whether maternal smoking is associated with congenital defects, positive associations with cryptorchidism were found, but not with hypospadias. ${ }^{1,22,26}$ In our series, of the 40 patients with DS, only one (2.5\%) presented hypospadias. The low prevalence of this malformation found in this group of patients hinders an assessment of the significance of smoking habit in the genesis of hypospadias in DS boys.

More and more consistently, congenital abnormalities such as cryptorchidism and hypospadias seem to be associated with cigarette consumption throughout pregnancy and even before conception.

The damages provoked by these environmental factors can be permanent and irreversible. We hope that our study can contribute to alert health care professionals, patients and family members regarding the prevention of harm caused by urogenital malformations and its predisposing factors. Although the number of cigarettes was not measured, it is believed that there is no safe dose for its use during pregnancy.

\section{Conclusion}

The prevalence of cryptorchidism is high in patients with Down syndrome. A strong association between smoking parents and occurrence of cryptorchidism was verified, especially when it comes to maternal smoking.

\section{AcknoWledgements}

We thank all the patients with Down syndrome, parents and family members who believed and contributed to this study, and the Down Syndrome Clinic of the Department of Child and Adolescent Health (DSCA), of the Secretary of Health of the city of Juiz de Fora, Minas Gerais (Brazilian Public Health System).

\section{Resumo}

Associação entre tabagismo e criptorquidia na síndrome de Down

Introdução: A criptorquidia é uma condição comum e prevalente em pacientes com síndrome de Down. Fatores ambientais, como o tabagismo, estão associados a malformações fetais. A avaliação da prevalência do criptorquidismo e a associação com tabagismo dos pais na síndrome de Down podem contribuir para alertar os profissionais de saúde e familiares sobre a prevenção dos danos causados pelo criptorquidismo e os possíveis fatores predisponentes.

Objetivo: Avaliar a prevalência de criptorquidismo na síndrome de Down e a associação com tabagismo materno e paterno.

Método: Quarenta (40) pacientes acompanhados em um centro de referência para atendimento da síndrome de Down foram avaliados por meio de questionário semiestruturado para avaliação de antecedentes parentais e características sociodemográficas, bem como de exames físico e laboratoriais complementares.

Resultados: Criptorquidia foi observada em $27,5 \%$ dos pacientes (IC95\% 15,98-42,96). Nesses pacientes, o criptorquidismo foi encontrado em $55 \%$ (5/9) das crianças cujas mães fumavam e em 19,35\% (6/31) daquelas cujas mães não fumavam $(\mathrm{OR}=5,26$ [IC95\% 1,06-25,41]; $\mathrm{p}=0,032$ ). Do mesmo modo, o tabagismo paterno foi observado com maior frequência entre crianças com criptorquidia, $63,36 \%$ (7/11) e 31,03\% (9/29), respectivamente $(\mathrm{OR}=3,89$ [IC95\% 0,91-16,73]; $\mathrm{p}=0,060)$.

Conclusão: A prevalência de criptorquidismo é alta em pacientes com síndrome de Down. Podemos mostrar uma forte associação entre hábito tabágico dos pais e ocorrên- 
cia de criptorquidismo, especialmente no caso de tabagismo materno.

Palavras-chave: hábito de fumar, síndrome de Down, criptorquidismo, doenças urológicas.

\section{References}

1. Hackshaw A, Rodeck C, Boniface S. Maternal smoking in pregnancy and birth defects: a systematic review based on 173687 malformed cases and 11.7 million controls. Hum Reprod Update. 2011; 17(5):589-604.

2. Ebert AK, Brookman-Amissah S, Rösch WH. [Urological manifestations of Down syndrome: significance and long-term complications - our own patient cohort with an overview]. Urologe A. 2008; 47(3):337-41.

3. Kupferman JC, Druschel CM, Kupchik GS. Increased prevalence of renal and urinary tract anomalies in children with Down syndrome. Pediatrics. 2009; 124(4):e615-21.

4. Perluigi M, di Domenico F, Fiorini A, Cocciolo A, Giorgi, A, Foppoli C, et al. Oxidative stress occurs early in Down syndrome pregnancy: A redox proteomics analysis of amniotic fluid. Proteomics Clin Appl. 2011; 5(3-4):167-78.

5. Hultén MA, Patel SD, Westgren M, Papadogiannakis N, Jonsson AM, Jonasson J, et al. On the paternal origin of trisomy 21 Down syndrome. Mol Cytogenet. 2010; $3: 4$

6. Weijerman ME, Winter JP. Clinical practice. The care of children with Down syndrome. Eur J Pediatr. 2010; 169(12):1445-52

7. Lyle R, Béna F, Gagos S, Gehrig C, Lopez G, Schinzel A, et al. Genotypephenotype correlations in Down syndrome identified by array CGH in 30 cases of partial trisomy and partial monosomy chromosome 21. Eur J Hum Genet. 2009;17(4):454-66.

8. Wiseman FK, Alford KA, Tybulewicz VL, Fischer EM. Down syndrome: recent progress and future propects. Hum Mol Genet. 2009; 18(R1):R75-83.

9. Barthold JS, Reinhardt S, Thorup J. Genetic, maternal, and environmental risk factors for cryptorchidism: an update. Eur J Pediatr Surg. 2016; 26(5):399-408.

10. Karaman A. Medical problems in children with Down syndrome in the Erzurum area of Turkey. Genet Couns. 2010; 21(4):385-95.

11. Mégarbané A, Ravel A, Mircher C, Sturtz F, Grattau Y, Rethoré MO, et al. The 50th anniversary of the discovery of trisomy 21 : the past, present, and future of research and treatment of Down syndrome. Genet Med. 2009; 11(9):611-6.

12. Chacko JK, Barthold JS. Genetic and environmental contributors to cryptorchidism. Pediatr Endocrinol Rev. 2009; 6(4):476-80.

13. Barthold JS. Undescended testis: current theories of etiology. Curr Opin Urol. 2008; 18(4):395-400
14. Acikbas I, Tomatir AG, Akdag B, Koksal A. Retrospective analysis of live birth prevalence of children with Down syndrome in Denizli, Turkey. Genet Mol Res. 2012; 11(4):4640-5.

15. Damgaard IN, Jensen TK; Nordic Cryptorchidism Study Group, Petersen JH, Skakkebaek NE, Toppari J, Main KM. Risk factors for congenital cryptorchidism in a prospective birth cohort study. PLoS One. 2008; 3(8):e3051.

16. Jensen MS, Toft G, Thulstrup AM, Bonde JP, Olsen J. Cryptorchidism according to maternal gestational smoking. Epidemiology. 2007; 18(2):220-5.

17. de Carvalho Mrad FC, de Bessa J Jr, de Rezende Duarte AM, Vieira AA, Araujo FC, de Sá Camargo ML, et al. Prevalence of lower urinary tract symptoms in individuals with Down syndrome. J Pediatr Urol. 2014; 10(5):844-9.

18. Hasen J, Boyar RM, Shapiro LR. Gonadal function in trisomy 21. Horm Res. 1980; $12(6): 345-50$

19. Mercer ES, Broecker B, Smith EA, Kirsch AJ, Scherz HC, A Massad C. Urological manifestations of Down syndrome. J Urol. 2004; 171(3):1250-3.

20. Strandberg-Larsen K, Jensen MS, Ramlau-Hansen CH, Grønbæk M, Olsen $\mathrm{J}$. Alcohol binge drinking during pregnancy and cryptorchidism. Hum Reprod. 2009; 24(12):3211-9.

21. Damgaard IN, Jensen TK, Petersen JH, Skakkebaek NE, Toppari J, Main KM; the Nordic Cryptorchidism Study Group. Cryptorchidism and maternal alcohol consumption during pregnancy. Environ Health Perspect. 2007; 115(2):272-7.

22. Virtanen HE, Toppari J. Epidemiology and pathogenesis of cryptorchidism. Hum Reprod Update. 2008; 14(1):49-58.

23. Spritzer DT, Peruzzo J, Peres, RM. Álcool, fumo e outras drogas. Federação Brasileira de Associações de Ginecologia e Obstetrícia. Manual de Teratogênese em Humanos. São Paulo: Federação Brasileira de Associações de Ginecologia e Obstetrícia; 2011. Cap. 35, p. 383-95.

24. Ion RC, Wills AK, Bernal AL. Environmental tobacco smoke exposure in pregnancy is associated with earlier delivery and reduced birth weight. Reprod Sci. 2015; 22(12):1603-11.

25. Ko TJ, Tsai LY, Chu LC, Yeh SJ, Leung C, Chen CY, et al. Parental smoking during pregnancy and its association with low birth weight, small for gestational age, and preterm birth offspring: a birth cohort study. Pediatr Neonatol. 2014; 55(1):20-7.

26. Skakkebaek NE, Rajpert-De Meyts E, Main KM. Testicular dysgenesis syndrome: an increasingly common developmental disorder with environmental aspects. Hum Reprod. 2001; 16(5):972-8.

27. Salemi M, La Vignera S, Castiglione R, Condorelli RA, Cimino L, Bosco P, et al. Expression of STRBP mRNA in patients with cryptorchidism and Down's syndrome. J Endocrinol Invest. 2012; 35(1):5-7.

28. Osugo M, Morrison J, Allan L, Kinnear D, Cooper SA. Prevalence, types and associations of medically unexplained symptoms and signs. A cross-sectional study of 1023 adults with intellectual disabilities. J Intellect Disabil Res. 2017; 61(7):637-42 